\title{
Critical Discourse Analysis of Imran Khan's Speech at Global Peace and Unity Forum.
}

\author{
Muhammad Imran Shah Rafia Alyas \\ Department of Applied Linguistics, Government College University Faisalabad
}

\begin{abstract}
The research had been conducted for the critical discourse analysis of Imran Khan's speech at Global peace and unity forum. The aim of this research is to examine how the language helps to build the ideology of the political leaders. How Political leaders choose special lexicons to manifest their power of thought to the audience. In this research paper, the Halliday's ideational metafiction has been used to investigate how the political leaders control the mind of the mass through their ideology. The quantitative approach has been used for the analysis. Results and conclusion are also provided at the end of the research.
\end{abstract}

Keywords: Critical Discourse Analysis, Ideational metafictions

DOI: $10.7176 /$ RHSS/9-1-05

\section{Introduction}

Discourse Analysis

A language is a tool of communication. It helps to present ideas and thoughts in front of others. The language of a person reflects its cultural identity. Language performs different roles in society which can be observed in politics, institutions, education, religion and many other areas. The use of the language is so natural that it becomes hard to identify how many functions a language performs in a society. The language of action in a certain context is called discourse. It is used to denote language beyond sentence level and includes a series of texts. According to Tischer (2000, p. 42), "discourse is a broad term with different definitions, which 'integrate a whole palette of meanings". Sunderland (2002) adds the interpersonal focus to this definition, stressing that discourse is not only a supra-sentential element but that it is functional in terms of language use, which means that it communicates meanings in a certain context. Also, discourse is used to refer to the language particular to certain social situations (e.g. Classroom discourse).

\section{Critical Discourse Analysis:}

The significant feature of the DA is to study the written and spoken text in social contexts. DA primarily concerned with the inner structure of texts. Halliday presented a new approach of systematic functional linguistics (SFL) against it. In mere words, text should be produced, apprehended and then place into a social context. Therefore, one can state that there is a significant relationship between language and society. In 1992, Fairclough presented an approach which is grounded in the combined study of language and social theories. A very similar domain was introduced at the end of the 1970's, which is known as Critical Discourse Analysis. The focus of CDA is to investigate how text is represented, misused and resist other powers in the social and political context. CDA also investigates how social power is implicated through language. The primary work in CDA is the work of Norman Fairclough who has presented the three dimensional framework. The basic purpose of this framework is to analyze how discourse is practiced (produced and implemented) in societal context.

\section{Systemic Functional Grammar:}

For the purpose critical discourse analysis, one of the most important theories, which is appreciated by many well-known linguists such as Fairclough and Kress, is Halliday's Systemic Functional Grammar. This theory has the significant role in the critical interpretation of linguistic expression in various discourses. According to this theory, "Language is functional" (Halliday and Hassan, 1989). It means that there are two ways to analyze the text, a productive way, when a text is studied through its linguistic components, and a semantic way when the intentional meanings are interpreted behind the text. Michael Halliday showed how meanings are represented in clause structures. According to Halliday (1994), text should be studied in terms of meanings and and use of phrases rather than the combination of words and structures. Halliday presented these meaning as three metafunctions of language in SFL. These are as follows

- Ideational function

- Interpersonal function

- Textual function

\section{Ideational Function}

Language is used to represent/make sense of the world. Whenever we talk, we express in language. For example, if we are at office, we discusses about our work, profit and loss in business to some other colleague. So our 
language is another name of our experiences. These experiences are showed by some lexical choices and through transitivity process: Clause as representation.

\section{$>$ Lexical Choices}

The lexis we choose influence how we and other people see things.

\section{$>$ Transitivity}

- Participant

- Process

- Circumstances

\section{Interpersonal function}

Language is used to position people and construct relationships between the addressee and the listener.

\section{Textual Function}

Language that is used to structure texts. It highlights the aspects what we want to say. Textual function identifies cohesion and its types, lexical cohesion and references etc.

\section{Literature Review}

- Massoud Sharififar and Elahe Rahimi (2015) critically analyzed the speeches of Obama and Rouhani which they delivered at the UN in 2013. The basic aim of this research is to analyze how both political leaders manifest their power through speeches. The approach of Halliday's systemic functional linguistics was applied by the researchers. The analysis was mainly conducted through the transitivity and modality system to show how the language performs its role to form an ideology and power in the speeches. Quantitative approach was used by the researchers to make statistical comparisons between both leaders' language usage. At the end of the research, the researcher compares the research of both politicians as well as signalize that both leaders used personal pronoun to create familiarity with audience.

- Maya Alaei1 \& Saeideh Ahangari from Islamic Azad University, Tabriz, Iran (2016), critically analyzed the text "Heart of Darkness" written by Joseph Conrad's. The aim of the research was to study how the ideology was developed and what type of lexico-grammatical strategies had been adopted by the author in the beginning section of the novel to convey the ideological meaning. It also looked into the contribution of literature within the theoretical accounts in which language forms. To meet the purpose of the research, the approach of Halliday's systemic functional linguistics has been used by the researcher. All the work had been done through quantitative approach.

- Hafiz Ahmad Bilal from University of Sargodha (2012), analyzed the text "Thank You M'am" through the Halliday's Systemic Functional Linguistics approach. The text had interpreted through three metafunctions of language which are ideational function, interpersonal function and textual function. Qualitative approach had been used by the researcher for the analyses of the text. While sharing his point of view at the conclusion of the research, Muhammad Bilal suggested that linguistic features help to find out intentional meanings behind the utterances of the speakers, but it would be more beneficial to critically study the text for its better understanding.

- Amna Iqbal, A student of The University of Lahore, analyzed the prominent politicians' speeches in 2015. The purpose of the research was to find out the rhetorical devices pre and post elections speeches of well-known political leaders. The researcher used qualitative approach to deal with research questions. The quantitative approach had also been used by the researcher to find out the frequency of persuasive devices and their implication before and after elections. At the end of the analysis, the researcher uncovered how politicians exploit rhetorical devices to assert their power.

- Sehrish Naz, an MPhil candidate of the Institute of English and Modern Languages in 2012, did the transitivity analysis of the political speech of Benazir Bhutto. The quantitative approach had been used to show the physical features of her language use. This research shows that Benazir knew how to play with words and had the ability to utilize them according to the state of affairs. Her linguistic choices of words rapidly convinced the Pakistani folks towards her ideology.

- Shakeel Ahmad, University of Sargodha (2012), had critically analyzed the political speeches of ousted Prime Minister Nawaz Shrief. Data had been taken from some audio speeches and from the extracts of Dawn newspaper. The qualitative approach had been used by the researcher. The researcher unfolded the hidden ideology of Ex-PM's speeches by using the Van Dijk's framework of the CDA. The researcher terminated the research, while discussing the reasons of strikes of mass and showed Ex-PM's agenda to convenience them to stop it, because these strikes were against the sovereignty of the nation and were caused the murder of innocent people. 
- Muhammad Munir from Gift University Gujranwala did the work on CDA in 2014. The purpose of his research was to critically analyze the selected speeches of Benazir Bhutto and to analyze how individual female political leader generates her ideology when many other ideologies were standing against her. The persuasive strategies and hidden meaning were also examined by the application of Fairclough's model. The qualitative approach was used by the researcher for the depth study of the text.

\section{Objectives}

- To examine the lexical choices in Imran Khan's speech for building the opinion.

- To investigate the frequency and distribution of transitivity processes.

\section{Research Questions}

- How lexical choices help to build the opinion.

- What is the frequency and distribution of transitivity processes?

- Which transitivity process has been used the most and why?

\section{Theoretical Framework}

Research Methodology:

In this research, quantitative approach has been applied to analyze the ideational functions in Imran Khan's speech on terrorism at UK. UAM software has been used to investigate the frequency and distribution of transitivity processes and personal pronouns used by Imran Khan.

\section{Data Analysis}

Ideational function consists of lexical choices and transitivity.

1) Lexical Choices:

Imran Khan's Speech consists of 1282 words and 57 sentences. Average sentence length is 22.5 and average word length is 4.69 . Lexemes density per sentence is 10.2 .

\begin{tabular}{|c|c|c|}
\hline Token & Frequency & Relative Frequency \\
\hline Islam & 57 & $1.61 \%$ \\
\hline western & 40 & $1.13 \%$ \\
\hline countries & 38 & $1.07 \%$ \\
\hline religion & 37 & $1.04 \%$ \\
\hline human & 36 & $1.01 \%$ \\
\hline people & 30 & $0.85 \%$ \\
\hline beings & 29 & $0.82 \%$ \\
\hline religions & 29 & $0.82 \%$ \\
\hline holocaust & 28 & $0.79 \%$ \\
\hline muslims & 26 & $0.73 \%$ \\
\hline 6 & 26 & $0.73 \%$ \\
\hline radical & 26 & $0.73 \%$ \\
\hline convey & 25 & $0.70 \%$ \\
\hline other & 23 & $0.65 \%$ \\
\hline make & 22 & $0.62 \%$ \\
\hline Muslim & 22 & $0.62 \%$ \\
\hline , & 20 & $0.56 \%$ \\
\hline understand & 19 & $0.54 \%$ \\
\hline justice & 18 & $0.51 \%$ \\
\hline great & 18 & $0.51 \%$ \\
\hline just & 17 & $0.48 \%$ \\
\hline called & 17 & $0.48 \%$ \\
\hline two & 17 & $0.48 \%$ \\
\hline tell & 16 & $0.45 \%$ \\
\hline hurts & 16 & $0.45 \%$ \\
\hline think & 16 & $0.45 \%$ \\
\hline peace & 15 & $0.42 \%$ \\
\hline get & 15 & $0.42 \%$ \\
\hline sacred & 15 & $0.42 \%$ \\
\hline
\end{tabular}


2) Transitivity Analysis:

In SFG, a clause is constructed from three elements. Which are as follows

$>$ Participant: People or things involved in the process.

$>$ Processes: Actions involved in the sentence.

$>$ Circumstances: Who, Where, When, How, Why the process occurred.

Feature

\begin{tabular}{|c|c|c|}
\hline FRAMMATICAL-RANK & \multicolumn{2}{c|}{ Nercent } \\
\hline Participant & 212 & $30.68 \%$ \\
\hline Process & 184 & $26.63 \%$ \\
\hline Circumstance & 87 & $12.59 \%$ \\
\hline
\end{tabular}

Process Types:

In 1985, Halliday presented the model of process types. In which he divides the process into four types.

\begin{tabular}{|c|r|r|}
\multicolumn{2}{|c|}{ N=691 } \\
\hline CLAUSE-TYPE & N & \multicolumn{1}{c|}{ Percent } \\
\hline Feature & 66 & $9.55 \%$ \\
\hline Material & 30 & $4.34 \%$ \\
\hline Mental & 15 & $2.17 \%$ \\
\hline Verbal & 48 & $6.95 \%$ \\
\hline Relational & $4.95 \%$ & \\
\hline
\end{tabular}

1- Material Process:

Material process consists of action verbs such as activities which takes place the external world.

- Actor: Doer

- Goal: Done-To

- Range: The participant who benefits

\section{Examples:}

1- every messenger of God,

$$
\text { brought, }
$$

\section{Actor}

Process(action)

the message,

same To every human

2- No one ever

$$
\text { Blamed }
$$

Goal community,

\section{Actor}

3-Muslims

Actor

4- Give

Process(action)
have lived
Process(action)
Me

Hinduism for

Recipient

what they were

\section{Process(action) \\ 5- We \\ Actor \\ 6- Unfortunately,}

Recipient

\section{Circumstance}

have lived

\section{Process(action)}

Prophet(PBUH) are ridiculed, leadership

to convey to western countries

Circumstance

Actor

With other religion circumstance

about 15 minuted

to talk to you

Goal

Hindus

goal

the Muslim has failed

Process(action) that it pains and hurts us.

Goal

2- Mental Process:

Mental process consists of mental verbs such as perceptions, feelings and cognition.

Perceptive: To do with senses.

Cognition: To do with mind.

Affective: To do with feelings. 
Examples:

Animals Believe

in 'might is right', survival of the fittest whereas human beings have compassion and justice.

\begin{tabular}{|c|c|c|c|}
\hline Senser & Process(cognitive) & Circumstance & \\
\hline We & All & know & $\begin{array}{l}\text { that Islam believes in } \\
\text { plurality }\end{array}$ \\
\hline Senser & Circumstance & Process(cognitive) & Phenomenon \\
\hline We & Accept & $\begin{array}{l}\text { as Allah says in the Quran that it is through His } \\
\text { will that we are distributed in different } \\
\text { communities. }\end{array}$ & \\
\hline Senser & Process(mental) & Circumstance & \\
\hline $\mathbf{I}$ & Think & $\begin{array}{l}\text { it is about the time that OIC, the heads of } \\
\text { Muslim states... into jails. }\end{array}$ & \\
\hline Senser & Process(cognitive) & Phenomenon & \\
\hline $\mathbf{I}$ & Consider & this & $\begin{array}{l}\text { a failure of the Muslim } \\
\text { intellectuals and Muslim } \\
\text { leadership }\end{array}$ \\
\hline Senser & Process(cognitive) & Addressed & Phenomenon \\
\hline
\end{tabular}

3- Verbal Process:

Verbal process consists of saying verbs.

Sayer: The addresser

Verbiage: What is being said.

Receiver: The addressee

Target: The aim of the saying

1- All religions

\begin{tabular}{|l|l|l|l|}
\hline Sayer & Process(verbal) & Verbiage & \\
\hline $\begin{array}{l}\text { 2- then } \\
\text { Circumstance }\end{array}$ & the ayat & goes on to say & $\begin{array}{l}\text { that complete in being good } \\
\text { human beings }\end{array}$ \\
\hline $\begin{array}{l}\text { 3- Nowhere, } \\
\text { Circumstance }\end{array}$ & Sayer & Process(verbal) & Verbiage \\
\hline $\begin{array}{l}\text { to convert everyoneto one monoculture } \\
\text { or monoreligion }\end{array}$ & Sayer & tell & Us \\
\hline \begin{tabular}{l} 
Verbiage \\
\hline
\end{tabular} & & & \\
\hline
\end{tabular}

4- Relational Process:

The relational process tell us how being can be represent in the English clause (Eggins, 2004).

Identifying: The value exactly tell us who/what the token is.

Attributive: Attributive linked to the carriers; many entities can have the same attribute.

Examples:

\begin{tabular}{|c|c|c|c|}
\hline $\begin{array}{l}\text { The most important } \\
\text { thing, the point I } \\
\text { want to make } \\
\text { tonight }\end{array}$ & Is & This & $\begin{array}{l}\text { that it is extremely important for Muslims } \\
\text { to be able to convey to people living in } \\
\text { Western countries that there is no } \\
\text { correlation between Islam and Terrorism. }\end{array}$ \\
\hline Carrier & Process(Attributive) & Attribute & Dobj \\
\hline Why & Is & the Islam issue & \\
\hline Attribute & Process(Attributive) & Carrier & \\
\hline $\begin{array}{l}\text { The moderate } \\
\text { majority }\end{array}$ & Is & always & liberal \\
\hline Carrier & Proces & Circumstance & Attribute \\
\hline
\end{tabular}




\section{Diagram}

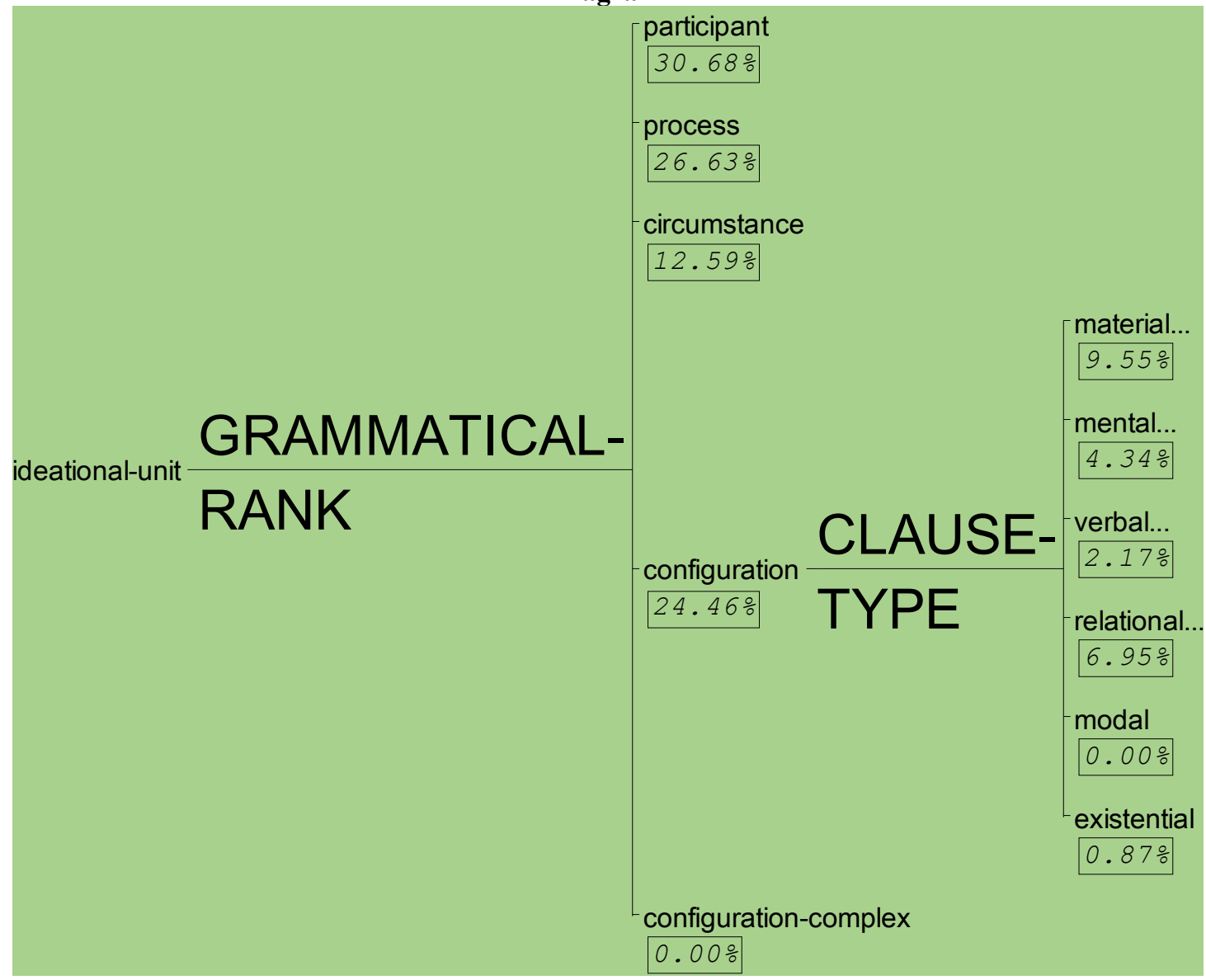

\section{Discussion/Conclusion}

As it has been seen that the frequency of the word "Islam" is 57 and then word western is " 40 " in the text which shows that the preferred discourse which is tried to build is about Islam and then western in the Imran Khan's speech. For over A decade Pakistan has been charged of terrorism simply because it has supported its militants against the Hindu tyranny in the disputed territory of Jammu and Kashmir. After the incident of 9/11 when the Al-Qaida targeted the world trade center and Pentagon, the misconception has been built that Islam is radical and extremist, Imran Khan while his address at Global Peace and Unity Forum defends Islam and tries to clarify to the western countries that there is no correlation between Islam and Terrorism. Islam is a peace loving religion.

In the most of the sentence the use of model verb "should" show the regression that Pakistani dictators have failed to frame the positive image of Pakistan in front of other countries. It also shows the failure of Pakistani dictators to prove that how 1.3 bn Muslims can be blamed of terrorism for the acts of 18 people. The most use of material verbs showed that the actions which should be taken by the government are not been taken and our dictators are the puppets of UK, on the name of liberalism. They failed to clarify that Islam promotes plurality, it accepts other regions and it is Allah's will who has divided us into religions and communities. The cognitive verbs accepting and believing shows that Muslims follow Allah's decisions and if they accepted communities how they are terrorist and why they will attack.

1. Sharififar, M., \& Rahimi, E. (2015). Critical discourse analysis of political speeches: A case study of Obama's and Rouhani's speeches at UN. Theory and Practice in Language studies, 5(2), 343-349.

2. Alaei, M., \& Ahangari, S. (2016). A Study of Ideational Metafunction in Joseph Conrad's" Heart of Darkness": A Critical Discourse Analysis. English Language Teaching, 9(4), 203-213.

3. Bilal, H. A. (2012). ANALYSIS OF THANK YOU M'AM: HALLIDAY'S METAFUNCTIONS. Academic Research International, 2(1), 726.

4. Iqbal, A. Discourse Analysis of Prominent Politicians' Public Speeches: Pre and Post-Election 2013, Pakistan.

5. Naz, S., Alvi, S. D., \& Baseer, A. (2012). Political Language of Benazir Bhutto: A Transitivity Analysis of Her Speech 'Democratization in Pakistan.'. Interdisciplinary Journal of Contemporary Research in Business, 4(8), 125-141. 
6. Ahmed, S. (2014). Critical Discourse Analysis of Prime Minister's Speeches on Harmful Aerial Vehicles (Drones). International Journal of Languages and Linguistics.

7. Munir, M. (2014). Critical Discourse Analysis of Benazir Bhutto's Selected Speeches.

8. Hasan, R., Matthiessen, C., \& Webster, J. (2005). Continuing Discourse on Language: A Functional Perspective Volume 1. Equinox Publishing Ltd..

9. Thompson, G. (2013). Introducing functional grammar. Routledge.

10. Eggins, S. (2004). Introduction to systemic functional linguistics. A\&C Black. 